УДК: 811.163.41’367.6

811.163.41:929 Белић А.

DOI: $10.18485 /$ belic_slv.2016.1.ch17

\title{
Сања Ђуровић
}

\section{ЗНАЧАЈ БЕЛИЋЕВИХ ПОГЛЕДА НА ВРСТЕ РЕЧИ}

1. Огроман значај књиге О језичкој природи и језичком развитку А. Белића видан је и по томе што је то и данас основна литература за многа истраживања. За ову прилику изабрана су четири поглавља из првог дела књиге О језичкој природи и језичком развитку и то она која се директно тичу Белићевих погледа на врсте речи („Један поглед на врсте речи”, „Свођење врста речи на четири групе”, „Значај неправих речи извесних категорија за врсте речи” и „Вредност поделе речи на врсте”). Управо су овде изнети Белићеви погледи темељни за морфолошка истраживања и вишеструко вредни јер теоријских радова и промишљања о врстама речи, њиховом статусу, развоју и променама било је веома мало и то најчешће кроз анализу појединачних примера.

Овим поглављима претходе поглавља о речима (Самосталне и несамосталне речи, Именичке речи, Заменичке речи, Придевске речи, Глаголске речи, Прилошке речи, Одношајне (релационе) речи), Емоционални знаци (узвици)). Ту се детаљније даје опис сваке врсте речи понаособ, а затим се у овде изабраним поглављима сумирају резултати о врстама речи у целини.

Предмет рада јесте преглед Белићевих ставова о категорији врста речи које су и данас темељни у одрећењу једне класе. Јединство гласовног склопа, функције и значења, основно је правило по којем се речи сврставају у одређену врсту. У раду ће се дати опис и тумачење Белићевих виђења као и статус поменутих категорија у савременом српском језику. У неким сегментима даће се и шира слика о врстама речи која је дата у књизи $O$ језичкој природи и језичком развитку, али ће издвојена четири поглавља бити централна. У читавој књизи тема су директно или индиректно врсте речи и изабрана поглавља само су теоријска синтеза.

2. Врсте речи и њихови облици својим постојањем и формом изражавају наш однос према свету у којем живимо и радимо. Тако се у језику категоризација испољава кроз постојање врста или класа речи, које се међусобно разликују према дистинкцијама на које упућују, као и кроз промене облика тих речи који служе да те динстинкције изразе. Као једна од основних морфолошких категорија, врсте речи су полазиште за морфолошке анализе. 
3. Александар Белић све речи дели на: а) самосталне (оне које имају значење именице или реалног предмета) и б) несамосталне (које се морају употребљавати уз друге речи да их ближе одреде). Ова подела важи и данас. Белић истиче да је тешко све речи сврстати у групе по једном принципу. „Стварност међу њима претставља само именица, и то она која је знак реалног предмета; све остало, било да претставља нашу апстракцију, као што су придевске речи, било да претставља ма коју другу врсту речи - није ништа друго до свет појмова створених мишљењем нашим и сплет њихових узајамних веза” (Белић 1998:105). Све речи не обележавају подједнако на оригиналан или непосредан начин значење, функцију и облик појединих врста речи. Праве речи су оне где је остварено јединство функције, значења и гласовног склопа. На основу тога Белић прво издваја четири основне категорије индоевропских језика (именичке, придевске, глаголске, деиктичке (партикуле)) на основу којих се развило шест основних врста речи у праиндоевропским језицима: именичке, придевске, заменичке, глаголске, прилошке и одношајне. Основне или најелементарније категорије су именице, придеви и глаголи. Само именице имају потпуно значење и изван реченице, а све остале речи добијају право значење тек у реченици.

3.1. Белић разликује праве и неправе врсте речи. „То показује да није довољно да се промени функција речи, па да се добије одмах и потпуно ново значење њихово. Ако главни према глава значи нешто сасвим друго, то није због тога што смо именичку функцију речи глава променили у атрибутску, већ зато што у различној употреби у вези са речима именица глава може имати и оно значење које је у придевској речи главни; према томе наставак ни значио би само попридевљавање, које не мора значити промену значења основне речи, већ само промену њене функције” (Белић 1998: 110).

Праве су речи једне категорије за које наше језичко осећање јасно сазнаје да припада само једној врсти речи. Код њих имамо јединство значења, функције и облика. Стално настају од правих речи - неправе и обрнуто, и дефиниција врста речи обухвата увек цео збир тих речи. Подела на праве и неправе речи врши се у зависности од тога да ли се њихово значење и састав може повезати са значењем и основом неке друге врсте речи (нпр. неправи предлози настали од именица: дуж, крај, место или неправи предлози настали од прилога: близу, више, пре и сл.). Праве речи су немотивисане и непродуктивне, а неправе речи су мотивисане и продуктивне.

4. По Белићевом мишљењу, категоријална доминанта која управља речју при укључивању њеном у ову или ону врсту јесте синтаксичка 
функција. Значење је само једним својим аспектом повезано са синтаксом, а другим не. Семантички критеријум је основа, а синтаксичко-функционални - доградња класификације речи.

Категорије речи постају онда када речи постану искључиво речи стално исте намене тј. када одређено значење, функција и облик постану њихово стално обележје. Све речи, осим именица, морају се стварати у реченици, зато што је основица за реченицу наше мишљење, а све врсте речи стварају се мишљењем или у мишљењу. То вреди и за именице, али именице одговарају предметима у природи (уколико значе предмете) и тако имамо представу о њима. Тако придеви значе сталну особину и имају функцију атрибута, глаголи значе временску особину тј. особину која се као радња приписује предмету за извесно време и сл. Нема ниједне врсте речи која, употребљавајући се у реченици као њен део са другом наменом, није могла постајати и по функцији и по значењу која друга категорија речи. Реченица и функција у њој стваралачки су моменти у језику. Зато Белић истиче да врсте речи морају имати места и у синтакси (Белић 1998: 406).

Врсте речи се ни облички не јављају као једнаке величине. Придеви само условно имају форму лео, лепа, лепо - ови облици су истргнути из синтагми са именицама тих родова. Ово показује да су врсте речи само пролазно устаљене. Њих реченица стално прерађује и даје им нову намену. Зато Белић разликује у језику две функције: а) функцију делова реченичних и б) функцију засебних врста речи. Старије су функције реченичних делова и од њих се стварају услови (уз значење и друге моменте) за природу засебних врста речи и за оне функције које из те природе проистичу. Нпр. када именица постане предлог или прилог или сл., онда функција тог реченичног дела повлачи за собом дату реч и претвара је у реч нове категорије (Белић 1998: 407).

5. У чему је вредност поделе на врсте речи Белић износи у посебном поглављу (XII), где релативизује значај врста речи. Уп.: „...иако Кинези немају врсте речи у нашем смислу, они могу да их изразе. То значи да врсте речи постоје у самим речима као таквим и у оним односима који се, у зависности од њихове унутрашње садржине, од њихова језичког потенцијала, у вези речи развијају [...] Различите поделе речи у различним језичким групама и показују само шта је у њима добило засебно обележје, а не какве могућности изражавања у њима постоје” (Белић 1998: 113).

Подела на врсте речи показује језичка формална стања која су добијена у развитку тих језика. Зато она имају само историјску вредност. „Ја бих 
у том правцу ишао још даље и рекао бих да је формално обележавање језичких категорија кад оне могу бити изражене и без формалних елемената - језичко грађење, а оне категорије по значењу међу речима које се добивају духовним процесима у језику да претстављају језичко стварање. Ја мислим да је прво само од историског значаја у појединим језицима, а друго да је стално па је у основици и језичког грађења. У првом правцу језици се могу разликовати, али у другом - не могу. Језичко стварање у природи је самих речи и њихових односа, а језичко грађење зависи увек од формалних могућности које су различне у различним језицима и које су различне у различним епохама развитка истога језика" (Белић 1998: 113).

Важно је Белићево запажање да су врсте речи само пролазно устаљене. „Њих стално реченица, као непосредни израз нашег мишљења, према искуствима и операцијама самог мишљења, прерађује и даје им нову намену" (Белић 1998: 407). Многе речи су у језику условне. Кад реч промени своју функцију и постане реч нове категорије, она може дуго остати са старим обликом и у новом значењу (нпр. млада/млада). Било је покушаја да се речи класификују и независно од функције, облика и значења. Ипак, то су поделе изван језика као средства којим се људи служе. Мора се ићи за језиком и одређивати категорије његових особина по оним мерилима које сам језик примењује.

Белић сматра да није тачно да свака врста речи мора бити обележена и формалним елементима, како неки сматрају. Може бити, али не мора. Код нас је све засновано на значењу и функцији, а ако се придода и облик, он само допуњује то, не ствара ништа ново, јавља се као израз нечег што постоји, а не изазива га, не рађа (Белић 1998: 537).

У већини језика врсте речи се називају делови говора. „Наш назив „врсте речи” најмање је погодан јер их он некако изједначује по вредности, што у језику не врши. Уствари су врсте речи самостаљени одломии говора" (Белић 1998: 537). Пошто у говору врше различиту службу, и по значају су различити. Немају исти статус именице, заменице, придеви, глаголи и предлози, везници, речце. Када их назовемо истим именом, бришу се све разлике међу њима и стављају се у исти ранг. Белић је то назвао нетачношћу наше терминологије.

6. У савременом српском језику изнова се отвара питање врста речи, пре свега, у вези са процесом конверзије ${ }^{1}$. Већина речи у српском језику припада само једној врсти речи, али постоје и речи које су примарно

1 У српском језику се користи неколико појмова којим се означава прелазак једне врсте речи у другу и то: расцеп класа, стваралачки процеси у језику, конверзија, категоријална полисемија, декатегоријализација и сл. 
једна врста речи, али могу бити и нека друга (нпр. пре - прилог и пре предлог). Прелазак једне категорије речи у другу категорију речи Белић је називао стваралачким процесима у језику. Без обзира на термин који се користи ради се заправо о преласку једне врсте речи у другу. Тако једна именица, на пример, може постати предлог (нпр. nym до куће и кренуо је nym куће ${ }^{2}$, када је примарно и даље именица, али има функцију неправог предлога. Стога поједине врсте речи по пореклу делимо на праве и неправе, где у неправе спадају речи које примарно припадају некој другој врсти речи (нпр. заменички прилози, који су по пореклу заменице, а по функцији прилози).

6.1. Именице као отворена класа речи претрпеле су највише промена, првенствено, на лексичком нивоу, али то је имало утицаја и на промене на морфолошком плану. Услед адаптације страних именица повећава се број именица мушког рода (нарочито код именица које се завршавају на нетипичне наставке за српски језик типа $-y,-u$ или на вокалске групе), повећава се број непроменљивих именица, апсолутна доминација наставка -[j]y у инструменталу једнине именица на -ост (младошћy, paдошћy и сл.), и то без обзира на то да ли су оне праћене атрибутом или нез од новина у морфологији именица. Заменице као затворена класа речи стабилне су и ту нема новина. Бројеви су, такође, стабилни и осим постепеног укидања деклинације бројева два, три, четири, нема новина. У оквиру класе придева јавља се већи број непроменљивих придева ${ }^{4}$ као резултат позајмљивања и адаптације, перифрастична компарација ${ }^{5}$ и свођење на придевску деклинацију. Код глагола се промене највише огледају на лексичком плану тако што се услед позајмљивања јавља све већи број глагола на -ирати и -исати који се најчешће примарно адаптирају као двовидски и оставља се простор да се у току потпуне адаптације преиспита и видско обележје ових глагола. Убедљива превага аориста по I врсти (дакле, с основом на консонант) гл. (-)дати, имати, (-)стати и хтети (дадох, имадох, стадох, хтедох), а презента по III врсти на -нем глагола типа лећи, рећи, срести и сл., (легнем, рекнем, сретнем). Укинути су бројни дублети у презенту код глагола зидати (зидам/зићем), шетати (щетам/шећем) и сл. ${ }^{6}$ Укинута је дихотомија код глагола на -ети/-ити у корист глагола на -ити (нпр. остарити/остарети). Све је

\footnotetext{
${ }^{2}$ О овим примерима конверзије писала је Драгићевић 2012.

3 Детаљније о овом питању в. Николић 2010.

${ }^{4}$ Више в. Николић 1996.

${ }^{5}$ Више о перифрастичкој компарацији в. Ковачевић 2003.

${ }^{6}$ Детаљније о томе в.Ђуровић 2015.

7 Детаљније о овом питању в. Спасојевић 2014.
} 
чешћа употреба перифрастичног футура или футуроида ${ }^{8}$. Ово су само неке од бројних морфолошких иновација које су настале или услед упрошћавања унутар система или су изазване страним утицајем.

6.2. Код непроменљивих речи нема морфолошких новина као код променљивих речи, што је и очекивано. И даље је отворено питање статуса класе код појединих врста, нпр. код узвика, где најчешће није испуњен основни Белићев критеријум - јединство облика (нпр. ау, ауу, аууууу и сл.). ${ }^{9}$ Непроменљиве речи су занимљиве, пре свега, због учесталих примера конверзије. Потреба за њиховом детаљнијом анализом и правцима категоријалне полисемије ${ }^{10}$ (прилог-предлог, предлогприлог, прилог-везник и сл. $)^{11}$ умногоме би олакшала и разумевање и усвајање ових класа. У пракси се показује да је управо због бројних примера конверзије у оквиру непроменљивих речи и ученицима и студентима много теже да савладају непроменљиве него променљиве речи.

6.3. Поред поменутих појава, морају се поменути и примери попридевљавања радног глаголског придева, трпног глаголског придева и глаголског прилога садашњег, затим функционално и семантичко разједначавање дублета и тежња ка укидању дублетизма у оквиру свих класа где се јављају.

7. Може се закључити да се данас традиционално све речи деле на десет класа и као критеријум за одређење припадности једној класи примењује се јединство облика, значења и функције. Подела на десет врста речи често је критикована и Белић сматра с правом. Као и свака друга класификација ни ова на врсте речи није идеална, јер такве не постоје, али задовољава основне принципе свеобухватности и економичности.

Значај Белићевих теоријских оквира које је изнео у књизи О језичкој природи и језичком развитку огроман је из више разлога. Прво, поставио је темеље, покренуо бројна питања, дао решења. Друго, других теоријских радова о овом питању у србистици скоро да нема и сви радови у вези са врстама речи ослањају се на Белићеве погледе. Треће, стваралачки процеси које је Белић помињао су нешто што је и данас остало неиспитано у потпуности у србистици. Четврто, његов рад представља неисцрпни материјал за нова размишљања и преиспитивања.

\footnotetext{
${ }^{8}$ Више о овом питању в. Војводић 1995, 1996; Симић 2009; Ковачевић 2014.

9 О статусу узвика више в. Јокановић-Михајлов 1998.

10 Термин који предлаже М. Ивић 2007.

11 О конверзији прилога в. Ивановић 2009.
} 
Детаљно су описане класификације врста речи у граматикама ${ }^{12}$ и ту се показују различите поделе и критеријуми, али класификација је само полазиште. Србистици је неопходан савремени теоријско-терминолошки оквир основних морфолошких категорија који би био утемељен на Белићевим и Стевановићевим радовима и преиспитан у односу на остале језике, а све у циљу јасније и прегледније слике статуса врста речи и граматичких категорија у савременом српском језику. Потребно је детаљније описати шта се дешава унутар сваке класе услед језичког развоја и страних утицаја, да ли се развијају нова обележја или долази до упрошћавања морфолошког система (губљења појединих обележја) и како се то одражава на категорију врста речи.

\section{ИЗВОРИ}

Белић 1998: Александар Белић, Опита лингвистика, Изабрана дела Александра Белића, том 1, Београд: Завод за уџбенике и наставна средства.

\section{ЛИТЕРАТУРА}

Војводић 1995: Дојчил Војводић, „Облици футура I као варијанте и/или као стандарди", Научни састанак слависта у Вукове дане, 24/1, 341-349.

Војводић 1996: Дојчил Војводић, „Статус футура I у књижевноуметничком и публицистичком стилу”, Јужнословенски филолог, II, 107-121.

Драгићевић 2012: Рајна Драгићевић, „О именицама у служби предлога”, Јужнословенски филолог, LXVIII, 91-111.

Ђуровић 2015: Сања Ђуровић, Укритаюе глаголских врста у конјугацији глагола, Крагујевац: Филолошко-уметнички факултет.

Ивановић 2009: Ненад Ивановић, „Прилози у служби других врста речи у српском језику", Зборник радова са првог научног скупа младих филолога Србије: Савремена проучавана језика и књижевности, год.1, књ. 1, Филолошко-уметнички факултет, Крагујевац, 149-166.

Ивић 2007: Милка Ивић, „Актуелни увиди у врсте речи”, Наш језик, 38/1-4, 5-7.

Јокановић-Михајлов 1998: Јелица Јокановић-Михајлов, „Узвици као врста речи”, Научни састанак слависта у Вукове дане, 27/2, 247-253.

Ковачевић 2003: Милош Ковачевић, „Перифрастичка компарација у српском књижевном језику", Граматичке и стилистичке теме, Бања Лука, 9-45.

12 Више о овом питању у докторату В. Ломпар. 
Ковачевић 2014: Милош Ковачевић, „Међуоднос футура првог и футуроида у савременом српском језику", Радови Филозофског факултета, 16, књ. 1/1, Филолошке науке, Пале, 9-38.

Лашкова 1998: Лили Лашкова, „Подела на врсте речи у словенским језицима - могућности и перспективе", Научни састанак слависта у Вукове дане, 27/2, 31-37.

Николић 1996: Мирослав Николић, „Непроменљиви придеви у српском језику", Наш језик, 31/1-5, 35-54.

Николић 2010: Мирослав Николић, „Облици инструментала једнине именица и врсте у српском књижевном језику”, Наш језик, XLI/3-4, 3-48.

Симић 2009: Радоје Симић, „Нормативни и употребни статус футуроида ћу/ ћеш... + да + презент", Научни састанак слависта у Вукове дане, 38/1, 51-55.

Спасојевић 2013: Марина Спасојевић, Глаголи на -(j)ети, -им у корелацији са глаголима на -ити, -им у савременом српском језику (нормативни и лексикографски аспект), Београд: Институт за српски језик САНУ.

Sanja Đurović

\section{IMPORTANCE OF BELIĆ'S VIEW ON WORD CLASSES}

Summary

Word class category is the basic morphological category and as such, in the Serbian language is represented by the traditional division into ten classes. The subject of the paper is an overview of the basic Belićs postulates about the word class category that is still fundamental in the definition of the classes. According to Belić, the unity between sound set, function and meaning, is one of the basic rule, according to which the words are set into the specific classes. The paper, based on the four chapters („A view on the word classes”, „Word class division into four groups", „The significance of irregular words of certain categories for word classes” and "The value of word division into the classes”) provides a description and interpretation of Belićs postulates and the status of the mentioned categories in the modern Serbian language. Many types of words are only conditionally classified, such as exclamations.

On the basis of Belićs view on the word classes, the situation in modern Serbian language was also depicted. The importance of Belićs theoretical framework presented in the book About linguistic nature and linguistic development is 
so big because of a number of reasons. Firstly, it set the foundations, launched a number of questions, gave solutions. Secondly, there are no other theoretical papers on this issue in the Serbian language and all works related to this issue rely on Belićs views. Thirdly, the creative processes mentioned by Belić are something that has remained not completely investigated to this day, in the Serbian linguistics. Fourthly, his work represents an inexhaustible material for new thinking and questioning. 